\title{
Remembering 1989 and its aftermaths in the depths of Russia
}

\author{
Caroline Humphrey
}

From a distance-I was glued to television and newspapers in Cambridge-nothing dramatic seemed to be happening in the Siberian provinces of Russia in 1989. All attention was focused on the amazing events in Germany, Czechoslovakia, Romania, and Bulgaria; yet I remember not only my astonishment at the tumbling of regimes but also constant twinges of regret and impatience that I could not be there. And "there" for me meant Mongolia and Buryatia, the regions I knew best, which now seemed hidden away behind the mysterious inactivity of the Soviet government. The reactions of ordinary people could only be guessed. As soon as I could make the arrangements, in the summer of 1990, I traveled to both countries. These are some recollections of that visit to Buryatia, a place geographically and mentally far from the liberation euphoria of Eastern Europe, yet as I was to discover experiencing its own unexpected perturbations.

By 1990, Buryatia still appeared more prosperous and better run than Mongolia (which is not necessarily the case today), with more technical equipment, educational and medical facilities, and above all a closer, more oppressive governmentality, a more pervasive caution. Traveling through rural districts I found collective farms in full Soviet mode: some proud of their vast flocks of sheep, others struggling to meet the plan. On the surface, it seemed not only that 1989 had passed like any other year, but that the people here were still coming to terms with perestroika. Many were the farm directors who told me that on no account would they give up their land and livestock for households or small teams to use under their own steam in the new lease system proposed years earlier in Moscow. For their part, ordinary farmers and fishermen were unwilling to take on the responsibility-it was too risky. A proposal to break up a large state fishing enterprise on Lake Baikal into smaller companies was turned down "democratically"; that is, at an open meeting where the workers protested that they wanted to keep their present jobs, houses, and salaries. Yet beneath the stasis, thoughts had begun to turn eastward to China. It was kept quiet, for this was an unheard of breach in the sacred state border still guarded by thousands of troops, but rural laborers had been invited from China to make good the lack in production of food. Near the frontier, in the Aga Buryat National Okrug (an entity that no longer exists), I met one hugely successful farm director who claimed to have introduced the perestroika reforms on his own initiative and who had been dismissed by disapproving regional party officials, but the economy was generally in the doldrums. Hard-headed Soviet officials were negotiating with the Chinese foreman in my smoky hotel how best to take advantage of the incomers' productivity but not "allow matters to get out of hand". Such were the rural preoccupations and no one breathed a word about Eastern Europe.

I had the sense that tectonic plates were shifting above all in the cities. The reforms-or was 
it the deepening crisis of the old system? - had resulted in rationing. There were queues in the streets for basic necessities, such as meat, butter, sugar, tea, and soap. My old academic supervisor had not been able to obtain bread for three days. People would wake up at 4 o'clock in the morning to get a good place in the queues. They would rouse the family "veteran" (many families could draw on a veteran of the Great Patriotic War or some other war who were entitled to priority rations) and dress him warmly, for even at the head of the queue he or she might have to stand for a long time. But suddenly, queues were losing their order. People started to ask "And what are you a veteran of? We women also suffered during the war" and they would put forward all kinds of other deserving claims. Sometimes veterans were elbowed aside and fights broke out. In other words, for the first time the categories of the established Soviet hierarchy of social worth were being publicly questioned, shaken.

For those who did not experience it, it is difficult to convey the depth of cautiousness, the inhibitions of those times. Unlike in Mongolia, where I had just met people who were open and active members of new political parties (Democratic and Green), in Buryatia any new organization-let alone a political party-was scarily subversive. I met a Buryat man living in Moscow who was in Ulan-Ude for a visit. He had organized a Center for Buryat Culture in the metropolis, was setting up a regional base in Ulan-Ude, and was trying to explain the need to publicize Buryat national concerns. "I don't know you," said my stony-faced Buryat companion. He provided the details of his local background, always necessary in these parts, and continued: "Don't you see how the Obkom is hiding the high infant mortality figures in Buryatia? We must make this public!" My companion hotly disagreed: "As soon as the doctor notices something wrong, he should do something practical about it. What's the use of all that noise made by your Center and its leader?" "Don't you criticize." Said someone else. "You should admire him for daring to speak out. He could easily be put away as an extremist." With a frown, my companion ushered me away from this conversation.

There was no escaping the ferment of talk that 1989 had made possible. The regional press, such as Pravda Buryatii, and the local television, which was just starting up, had been more or less silent on the events in Eastern Europe. But people could watch the entire drama on the Moscow channel, and it had been received with shock and confusion. Many thought this was just another "thaw," like Khrushchev's in the 1960s; a young and energetic General Secretary (Mikhail Gorbachev) had rashly engendered upheavals that would inevitably settle back to normal. Practically no one foresaw what would actually happen. Communists - who were strongly in power in Buryatia-were aghast at the foundering of the Warsaw Pact, the loss of "influence over Europe" and the desertion of "faithful friends," and they felt that Eastern Europe should be returned to its previous subordination at any cost. Because this view had been predominant among power holders in Buryatia, especially Russians, even in 1990 a prudent public silence still reigned about the events. Although no one said so, it was apparent to me that the non-intervention in Eastern Europe had lifted at least some part of the fear. Perhaps the actual issues raised in Germany, Czechoslovakia and other countries were too mind-boggling and unfamiliar-new forms of government, democracy, civil rights, even privatization and legitimate capitalism; in any event, my memory recalls no conversations about these matters. Instead, the preoccupations were with other previously forbidden topics.

The Buryats' imagination was eagerly reformulating the given version of their history, national mode of life, ecological niche, and place in the world. With hindsight the impassioned debates of 1990 can be seen as prescient, as these same themes are still central today, in much bolder forms. In the summer of 1990, it felt as though the eruptions of 1989-liberating waves that were refracted and diffused by the distance to Siberia-met and joined an internally generated upheaval with different intellectual sources. What was being questioned was the established 
Soviet structure of nations and territories. Deep historical formations were being called upon to show that this part of the world should be organized in a quite different way. I am going to explain, by citing some conversations from my field notebook.

Bair Taisaev, a painter, expressed the thoughts of many when he railed against the Siberian nationalist writer, Valentin Rasputin, who had lovingly described Russian peasant attachment to the lands around Lake Baikal.

"How dare he write that Buryats got drunk at shamanist rituals? Shamanism is the codified memory of the Mongolian people in their lands, their sacred places. We should return to the name Buryat-Mongol [the name had been reduced to Buryat by Stalin]. We should unite and we should shift our republic to the lands where our people actually live."

Taisaev was referring to the fact that Soviet policies had cut Buryat territories into three separate units-dividing the Republic from Buryats living in neighboring Russian-dominated provinces, moving Buryats from areas close to the Mongolian border, and including a huge area of virtually uninhabited forest to the north.

"We have been saddled with the image of a forest people-but all that, the taiga, sables, deer and so forth has nothing to do with us. Our econiche is to the south. We are people of the open steppe, with sheep and camels. Let us get rid of the forest and move the whole republic to the south, including the Hentei province of Mongolia, which is Buryat inhabited land. This is the area from which the great Mongol Empire originated. Genghis Chinggis Khan was a Buryat and he came from this region."

Behind all this was an idea I heard for the first time in 1990, the "gene-fund" (genofond). The Buryat gene-fund is especially strong, said Taisaev and his friends.

"We are like the Jews. In each town, the Buryats are the intelligentsia. The Mongols could never have managed to achieve their revolutionary socialism without leadership from the Buryats. But the Mongols and the Russians and the Chinese, they all put us down. Why? Because our strong tribal society was the basis of the structure of the Mongol Empire. The Europeans [i.e., the Russians] could never stand for an Asiatic power that could generate its own powerful new social formations. It was Stalin who set Mongols against Mongols and incited the Halha Mongols' genocide against the Buryats in the 1930s, who purged our entire intelligentsia and Party leadership at the same time, and who engineered the Chinese return of Buryat refugees to the USSR, where they were all killed. ${ }^{2}$ But because of our exceptional gene-fund, our peasants were able to rise again-it was left to them to recreate our literature, our theatre, our poetry, and our music. We are more talented than other people. But we are not known. People have heard of the Chukchi, but Buryatia, where is that?"

This kind of idea that the Soviet Union had carried out a leveling (uravnilovka) of nations-a deliberate policy to punish an outstanding people and make them just like any other "natives"and that this injustice should now be righted did not stem directly from any reflection on the events of 1989. It had little to do with actual political liberation, democracy, or an opening to the West. Rather it arose from, or at least was expressed in terms of, the ideas of Lev Gumilev, the writer son of poet Anna Akhmatova, who had been a prisoner (zek) held in camps for much of his youth. Gumilev wrote that certain peoples in certain propitious times and ecologically suitable circumstances will rise and flourish; they will be "passionary" societies, that is those destined to expand and rule over others. From rural truck drivers to city intellectuals, people told me, "Gumilev has become a star, everyone is reading him." One can see the attraction for the freed zek of the worship of power and vigor, and likewise the seductiveness of the idea for those Buryats who were coming to terms with repressed parts of their history. In 1990, the gene-fund and the passionary society were 
ways of thinking about national destiny, but paradoxically they were especially the preoccupations of people who had now-because of the recent revelations about history-been made to feel inadequate, squashed, divided, and diluted. In fact, as a Russian friend recalling 1989 reminded me, the popularity of Gumilev was not restricted to Asian people like the Buryats but was widespread also among Russians. For them, the talk of "passionary societies" went along with a new discussion of how it was the Russian people above all who had suffered as a result of Soviet policies ("at our expense, for the sake of all those others, we have been put down while they rise; when will our time come?").

Meanwhile, Buryats were asking how to catch the wave and turn the tide. Which traditions and native ways could be retrieved in order to allow the talents encoded in the gene-fund to triumph? Some strange ideas were bruited: an architect from west of Lake Baikal, having expounded on the rites and genealogies of his tribe, the Ekhirit, and the clans within it, exclaimed that a multi-party system might work in Moscow, but not here. We should set up a parliament based on clans. This would mean that every Buryat would be represented and that each clan could express its own will in its own way. A poet spoke rhetorically about the loss of the nomadic herding way of life and in particular the horse riding tradition ("our manner of riding massages the male organ and boosts our virility") and wondered how this loss could be righted in present circumstances.

The main, and most serious, discussions were about the inter-relations between particular peoples and their proper ecological niche, a subject also discussed by Gumilev. Certain cultures, with their characteristic values and ways of life, harmonize with particular eco-zones and it is this benign concatenation that brings about the flourishing of these peoples. In 1990 I attended a conference held on the shores of Lake Baikal to explore such ideas. Eschewing the wilder reaches of Buryat nationalism, the organizers proposed that Buryats, Russians, and Evenki were all peoples equally to be regarded as indigenous to the region and each having a legitimate way of in- habiting it. In my memory, though, Buryats were given by far the greatest prominence. Papers were given on pre-Soviet economies, on the Buryat respect for nature, on the spiritual aspects of the culture, about how to avoid and protest against environmental pollution, on how to revive the Buryat language in the younger generation, and on appropriate teaching methods in schools that would inculcate these values. The speakers were emboldened and encouraged by the participation in the conference of foreigners like myself and by the presence of sympathetic journalists from Moscow. Unofficial national leaders emerged into public figures at this conference, such as Sergei Shapkhaev, who was later to lead successful protests against the routing of oil and gas pipelines through reserves close to Baikal or through Buryat-inhabited territory, and Irina Urbanaeva, who became the celebrated author of books on the philosophical-spiritual heritage of Central Asia. In 1990, when they were just starting to speak publicly amid a wider atmosphere that was either hostile or merely curious, Shapkhaev and Urbanaeva formed an uncompromising and firm united front. They soon managed to find supporters among academics. But as the decade wore on their ways parted. Urbanaeva was to delve deeply into shamanism, which she interpreted as the exterior manifestation of tengrianism, ${ }^{3}$ which she described as one of the world's most ancient traditions of occult knowledge, an "observation of the heavens that plunged nomads into the mystery of immersion into infinity". Later she became an academic specializing in Buddhism and traditional ethics and their relevance for contemporary life. Shapkhaev was to take a practical and scientific route, becoming an internationally recognized professional environmentalist, author of surveys and ecological assessments, and director of the Buryat Regional Organization for Baikal.

The year 1989 opened the doors for a multitude of ideas, and it enabled Buryat people to rethink their place in the world. The first steps were made to link together half-forgotten cultural traditions with global concerns. But what was the longer term outcome? I have focused on 
Shapkhaev and Urbanaeva because I knew them and collaborated with them on a project on environmental conservation in the 1990s. Neither achieved political clout: the republic went on being ruled by the long serving former communist Potapov for many years and he was succeeded by a Putin-approved Russian.

Not only have the three Buryat regions not been united, but the two smaller ones, the Autonomous Okrugs, have disappeared off the map, absorbed into large Russian oblasts. Needless to say, wild talk of moving the republic southward never came to anything. But it would be wrong to conclude that all stirrings have ended. A number of European countries directed their eyes westward in 1989. In Siberia, the perspective opened to the east. The political lid is more firmly shut than ever, but the wild talk is wilder than ever: some people are arguing for a political union of Buryatia with Mongolia and especially Inner Mongolia, reviving the old pan-Mongolian idea. People observe that Beijing is closer than Moscow, they are trading with the east, and their children are flooding into Chinese universities. Mongolia used to be dismissed as backward, but these days, with the reverse in fortunes in the region, there is economic migration from Buryatia to Mongolia. No one knows where this may lead.

\section{Acknowledgments}

I am grateful to Ivan Peshkov and Galina Manzanova for helping me recall the Siberian experience of 1989/90.
Caroline Humphrey has worked in the USSR/ Russia, Mongolia, Inner Mongolia, Nepal, and India, researching anthropology of socialism/ post-socialism, religion, ritual, economy, history, language, and ethics. She is Rausing Professor of Collaborative Anthropology at the University of Cambridge and is researching migration, urban life, and coexistence in the Black Sea region.

E-mail: ch10001@cam.ac.uk.

\section{Notes}

1. The Mongols of Mongolia do not agree with this proposition and much resent Buryat attempts to claim the great emperor as their own.

2. Needless to say this is not an accurate historical account, but it does bring to the fore certain facts that were obscured by the official Soviet, Mongolian, and Chinese histories These include the leading role of Buryat socialists in Mongolia in the 1920s, the exceptionally high toll of Buryats in the purges of the late 1930s in both Mongolia and the USSR, and the SovietChinese agreement whereby many (but by no means all) Buryat refugees were returned to the USSR after World War II.

3. Tengri is the Mongolian and Buryat word for sky or heaven. 